\title{
"Determinant indicators for labor market efficiency and higher education and training: evidence from Middle East and North Africa countries"
}

\author{
AUTHORS \\ Elsayed A. H. Elamir (D https://orcid.org/0000-0002-9430-072X \\ R http://www.researcherid.com/rid/K-3340-2018
}

Elsayed A. H. Elamir (2020). Determinant indicators for labor market efficiency ARTICLE INFO and higher education and training: evidence from Middle East and North Africa countries. Problems and Perspectives in Management, 18(1), 206-218. doi:10.21511/ppm.18(1).2020.18

DOI http://dx.doi.org/10.21511/ppm.18(1).2020.18

RELEASED ON

Thursday, 12 March 2020

RECEIVED ON

Sunday, 15 December 2019

ACCEPTED ON

Thursday, 27 February 2020

\section{(c)) EY}

LICENSE

This work is licensed under a Creative Commons Attribution 4.0 International License

JOURNAL

"Problems and Perspectives in Management"

ISSN PRINT $1727-7051$

ISSN ONLINE $1810-5467$

PUBLISHER

LLC "Consulting Publishing Company "Business Perspectives"

FOUNDER

LLC "Consulting Publishing Company "Business Perspectives"

NUMBER OF REFERENCES

44
NUMBER OF FIGURES

2
NUMBER OF TABLES

11

(C) The author(s) 2021. This publication is an open access article. 


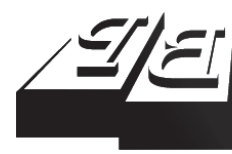

\section{BUSINESS PERSPECTIVES}

(O)

LLC "CPC "Business Perspectives" Hryhorii Skovoroda lane, 10, Sumy, 40022, Ukraine www.businessperspectives.org

Received on: $15^{\text {th }}$ of December, 2019 Accepted on: $27^{\text {th }}$ of February, 2020 Published on: $12^{\text {th }}$ of March, 2020

(C) Elsayed A. H. Elamir, 2020

Elsayed A. H. Elamir, Ph.D., Associate Professor, Department of Management and Marketing, College of Business Administration, University of Bahrain, Kingdom of Bahrain.

\section{DETERMINANT INDICATORS FOR LABOR MARKET EFFICIENCY AND HIGHER EDUCATION AND TRAINING: EVIDENCE FROM MIDDLE EAST AND NORTH AFRICA COUNTRIES}

\begin{abstract}
This study aims to explore the determinant indicators for the labor market efficiency and the higher education and training factors that can help in increasing the productivity in labor market and the quality in higher education and training, as well as pays attention to important relative indicators to improve the relationship between them. To achieve these aims the canonical correlation analysis is used as a bidirectional technique that allows studying the mutual relationship between two factors by taking advantage of available reports from 2012 to 2018 published by World Economic Forum (WEF).

The results indicate that the extent of staff training, internet access, quality of education, and quality of management schools are the most important indicators in higher education and training and most correlated with labor market efficiency factor. The capacity to attract talent, pay and productivity, cooperation in labor-employer relations, and reliance on professional management are the most important indicators in labor market efficiency and the most correlated with higher education and training factor. The commonality analysis gives interesting results and shows that the explained variance in labor market efficiency and higher education and training depends on common indicators rather than a unique indicator.
\end{abstract}

Keywords

canonical correlation, commonality analysis, firing, hiring, incentives, productivity, professional management, redundancy cost

\section{JEL Classification I23, M53, M54}

\section{INTRODUCTION}

The countries recognize that good higher education and training can significantly increase economic competitiveness. Recent researches suggest that the quality of higher education and training is strongly related to higher income and economic growth where the former can have a role in preparing youth for work and enhancing the skills of students to the labor market (Schoellman, 2012; Hanushek, 2013; Kaarsen, 2014; Manuelli \& Seshadri, 2014; Assaad \& Krafft, 2016; Dalton \& Smith, 2004; Kucczera \& Field, 2010; Assaad, Krafft, \& Salehi-Isfahani, 2018). The people who leave education often enter the labor market unprepared and experience difficulties in getting and job and are more likely to end up in low-quality jobs (Garcia \& Fares, 2008). Although many factors influence economic growth, such as political stability, governance and productivity, higher education institutions play an important role in supporting economic growth and encouraging social society participation not only due to their ability to produce and distribute knowledge but also to attract many students and people to learn them and create new skills (Pages \& Stampini, 2009; Assaad et al., 2018). 
Higher education and training are very important pillars for economies, especially modern globalization requires well-educated people who can adapt rapidly to fast-changing technology environment. This pillar measures the quality of education in terms of quality of the education system, quality of math and science education, quality of management school, and secondary and tertiary enrolment rate. Moreover, this pillar takes into consideration the extent of staff training that plays an important role in updating people's skills (Boeri \& Garibaldi, 2007; Porter \& Schwab, 2008). Labor market efficiency is a critical pillar for ensuring that the workers are in the most productive place for skill sets. The first point in the efficient labor market is its flexibility to promote productivity, rules, and regulations for fire workers and policy to attract and retain the best talents. Also, the labor market should be flexible to switch workers from one sector to another quickly at a low cost and allow wages to vary without social disruption (Dolado, Ortigueria, \& Stucchi, 2012; Porter \& Schwab, 2008).

This study explores the determinant indicators of higher education and training and labor market efficiency, as well as pays attention to the important relative indicators that exist in both education and labor market factors. Canonical correlation is used to capture the maximum correlation between education and labor market factors in terms of canonical correlation functions. The standardized coefficients and loading are obtained to determine the most important indicators in each factor. The cross-loading is used to study the impact of each indicator in one group on the canonical variate in other group. Redundancy is obtained to reflect the amount of variance in the original variables of one set of variables, which is explained by the canonical variate of other set of variables. Commonality analysis is used to demonstrate the canonical impacts made by using the variables in each canonical set to partition the variance of canonical variates produced from other canonical set.

The current study is useful for decision-makers in the MENA countries where it can help in improving labor market efficiency factor through education and training factor and consequently increase employability and economic growth in these countries. Moreover, if these countries can attract more talented workers and retain them, this surely will improve the relationship between education and labor market.

This study is organized as follows. The literature review is discussed in Section 1. The research methodology is provided in Section 2. The data analysis and the results are presented in Section 3. Final section is devoted to the conclusion.

\section{LITERATURE REVIEW}

Human capital theory is introduced by Becker (1962) who argued that workers have many skills and abilities, which they can improve through education and training. If human capital increases with extra education, the value of workers should theoretically increase in proportion to the amount of education they have obtained. According to Mincer and Polachek (1974), Rosen (1983), and Becker (1993), the human capital theory has presented the higher education and training as both public and private investment decision. The basic argument is that investing in education and training increases productivity, social stability, better-paying jobs, reduces waiting time to get a job and better lifestyle that lead to economic growth. Later, Saunders, and Machell (2000) developed the neo-correspondence theory promoting the relationship between students' experience and the labor market. The neo-correspondence theory concerns with increasing the skills that provide an image of what work is currently and what should be likely in the future by giving a high value to social skills, attitudes, motivation, broad knowledge, and flexibility (Nicolescu \& Paun, 2009).

Arthur (2006) and Little (2007) have considered the nature of graduate work that had significant changes, and they required higher education institutions to develop new skills and abilities in their students that are demanded by labor market (Nicolescu \& Paun, 2009). For example, Arthur (2006) listed some skills required by employers such as analytical skills, social skills, management skills, ability to learn, and presentation skills. 
Moreover, from Nicolescu and Paun (2009), Little (2007) named ten highly required skills at labor market, among them: effective use of time, working under pressure, coordinate activities, work productivity with others and rapidly acquire new knowledge. One of the yield aspects of higher education quality, the movement of students to work, is somewhat affected by the correspondence between the skills and abilities created during university studies and the ones required by labor market. In this regard, Kehm (1997) conducted a study on 12 nations in order to analyze the movement from higher education to work (Teichler, 1999; Teichler \& Schomburg, 2006).

In the REFLEX study, conducted in Europe during the period 2004-2007 in 16 countries, Allen and Velden (2007) found that five spheres of competence for students' success were: professional expertise, functional flexibility, innovation and knowledge management, mobilization of human resources, and international orientation. Also, the study mentioned that the graduates must be prepared by higher education to be willing to do specific tasks, not fundamentally the desired specialization in which they have been prepared. The REFLEX study ascertained that the courses should enhance on the quality of professional ability in conjunction with student-oriented strategies and should not disregard strategies emphasizing knowledge (Allen \& Velden, 2007). It is worth to mention that everyone does not completely join the faith that the generic skills should be given predominance in higher education. For example, Teichler (1999) noticed that the employers in their recruitment forms estimate the role of social ability and personality parts more than the cognitive aptitudes and the knowledge basis parts for specialization areas.

Garcia and Fares (2008) highlighted the effect of globalization and the technological changes on the labor market, where they focused on adaptability that plays an important role in the changes where the higher education institutions must deal with rapid changes in the technology. Fofack (2009) defined globalization as a significant reduction of time-scale in the movement of goods, capital, and knowledge in a spherical space, despite the constant distance between source country and final destination, as a result of technological advances and increasing interdependence and con- nectivity of world markets. Due to globalization, there is a competition and more demand for highskilled and flexible labor force both in large and small companies. Pages and Stampini (2009) emphasized a relationship between education and the labor market where education is a tool for reducing unemployment rates and poverty.

World Bank regional report (2010 and 2011) about MENA region identified the following reasons that prevent graduate students from getting a job: (a) the weakness of private sector: it recognized the problems of arbitrariness and unfair application of the "rules of the game" as the key issues that constraint private sector growth; (b) mismatch skills: it suggested that businesses listed worker skills and education among their top five business restrictions in the area. Employers communicate their satisfaction not only with shortcomings in relevant experience and technical skills but also with soft skills such as personality traits, social graces, leadership abilities, language, and personal habits. Thisse and Zenou (2000) state that unemployment is a result of the mismatch between the skills produced by the education and the demand of the labor market; (c) dominance of public section: despite the actual fact that the utilization growth of the general public section has slowed in recent years, public section employment still accounts for an outsized share of all formal sector employment in many countries in North Africa; (d) regulation and labor taxes: terminating guidelines in MENA remain very severe and redundancy cost remains high. While the end of laborers because of excess is lawfully approved in all MENA countries, most countries have complex guidelines that require notice, support, and endorsement for dismissals; (e) innovation and investments: MENA countries require improvements in the investment environment that favor innovation-based competition and commerce entry and exit. Also, MENA countries require to capitalize on diasporas overseas by displaying more extensive measures to support the link of high-skilled diasporas in research and innovation ventures in higher education and companies. Besides, it is important to develop to methods to increase the quality of tertiary education institutions and introduce entrepreneurship skills and commerce training in education module across specializations that can enhance creativity and innovative thinking. 
Tellegen (2013) used the human capital theory to analyze this relationship in Sub-Saharan Africa. A case study of the "The Netherlands Initiative for Capacity Development in Higher Education (NICHE)" program highlighted this relationship and showed how they related training and education with the demand of labor market. He concluded to the necessity in the improvements of the relationship between education and labor market. Boccanfuso et al. (2015) studied the relationship between quality of higher education and the labor market in Senegal where they used a large-scale reform launched in Senegal in 2000 to obtain difference in the estimates that suggested skilled workers experience 9\%-point employment gain to young workers better than older workers. More recently, Assaad et al. (2018) studied the relationship between the type of higher education and labor market outcomes in Egypt and Jordan. They investigated the effect of the type of higher education institution an individual attend on many labor market outcomes. They concluded that supply-side issues and institutional incentives had minimal effect on labor market outcomes, while family relationship has the most important role and they suggested increasing the role of the private sector in the higher education.

This study is unique and different from others in terms of study indicators where many of them not used in previous studies, MENA region with 18 countries and canonical correlation method.

\section{RESEARCH METHODOLOGY}

A brief discussion is given to canonical correlation analysis that measures the linear relationship between two different groups of indicators. The data collection and indicators of the study factors are also discussed.

\subsection{Canonical correlation analysis}

Canonical correlation analysis is an advantageous technique to study and measure the rapport between two groups of variables, and each group consisting of two or more indicators. The canonical correlation analysis characterizes the orthogonal linear combinations of the variables called canonical functions inside each group that can clarify the relationship between and within two groups. For example, if we have two groups of variables $V=\left(V_{1}, \ldots, V_{p}\right)$, which has $p$ indicators and $Z=\left(Z_{1}, \ldots, Z_{q}\right)$, which has $q$ indicators, the canonical correlation analysis can obtain the orthogonal linear combinations of $V$ and $Z$ that have the highest value of correlation with each other as $M=a^{\prime} V$ and $H=b^{\prime} Z$. Note that the highest number of canonical functions ( $M$ and $H$ ) that can be found equals the least variables in any group $(p, q)$. For example, if the first group consists of 8 indicators and the second group consists of 10 indicators, the maximum canonical functions that can be obtained are $(8,10)=8$ (Dattalo, 2014; Knapp, 1978; Stevens, 1996; Hair, Anderson, Tatham, \& Black, 1998; Warner, 2008; Mousa \& Elamir, 2019).

\subsection{Data collection and study indicators}

Canonical correlation analysis has been implemented based on the annual global competitiveness reports issued by World Economic Forum (WEF). This is an international organization founded in 1971 as a not-profit organization. WEF set up the global competitive index (GCI) that measures the level of nation's competitiveness using twelve pillars to obtain a competitive ranking in each pillar and overall ranking among countries (Porter \& Schwab, 2008). The current study used WEF reports from 2012 to 2018 to elicit the scores for the two groups of pillars from GCI, namely, Higher education and training and labor market efficiency for 18 countries in the Middle East and North Africa (MENA), namely, Algeria, Armenia, Azerbaijan, Bahrain, Cyprus, Egypt, Georgia, Jordan, Kuwait, Lebanon, Morocco, Oman, Qatar, Saudi Arabia, Tunisia, Turkey, United Arab Emirates, Yemen. Some other countries are excluded because of partially or fully unavailable data, such as Libya, Syria, and Iraq. Therefore, the sample size that used in study is 126 .

Moreover, Table 1 shows that the labor market efficiency factor includes 10 indicators and higher education and training factor includes 8 indicators. Note that MENA countries have a wide range of economics and incomes where there are high-income countries such as Gulf countries, meddle-income countries such as Egypt and Jordan, and low-income countries such as Yemen. 
Table 1. Higher education and training and labor market efficiency factors and their indicators

\begin{tabular}{|c|c|c|c|}
\hline No. & Indicator & Notation & Description \\
\hline \multicolumn{4}{|c|}{ First group: Higher education and training $(\mathrm{X})$} \\
\hline 1 & $\begin{array}{l}\text { Secondary education } \\
\text { enrolment rate gross \% }\end{array}$ & $\mathrm{X} 1$ & Gross secondary education enrolment rate \\
\hline 2 & $\begin{array}{l}\text { Tertiary education enrolment } \\
\text { rate gross \% }\end{array}$ & $x 2$ & Gross tertiary education enrolment rate \\
\hline 3 & $\begin{array}{l}\text { Quality of the education } \\
\text { system }\end{array}$ & $\mathrm{x} 3$ & $\begin{array}{l}\text { How well does the educational system in your country meet the needs of a } \\
\text { competitive economy? }[1 \text { = not well at all; } 7 \text { = very well] }\end{array}$ \\
\hline 4 & $\begin{array}{l}\text { Quality of math and science } \\
\text { education }\end{array}$ & $\mathrm{x} 4$ & $\begin{array}{l}\text { How would you assess the quality of math and science education in your } \\
\text { country's schools? }[1=\text { poor; } 7=\text { excellent }- \text { among the best in the world }]\end{array}$ \\
\hline 5 & $\begin{array}{l}\text { Quality of management } \\
\text { schools }\end{array}$ & $x 5$ & $\begin{array}{l}\text { How would you assess the quality of management or business schools in your } \\
\text { country? }[1=\text { poor; } 7=\text { excellent - among the best in the world] }\end{array}$ \\
\hline 6 & Internet access in schools & $x 6$ & $\begin{array}{l}\text { How would you rate the level of access to the Internet in schools in your } \\
\text { country? }[1 \text { = very limited; } 7 \text { = extensive] }\end{array}$ \\
\hline 7 & $\begin{array}{l}\text { Local availability of specialized } \\
\text { training services }\end{array}$ & $x 7$ & $\begin{array}{l}\text { In your country, to what extent are high-quality, specialized training services } \\
\text { available? }[1=\text { not available; } 7=\text { widely available }]\end{array}$ \\
\hline 8 & Extent of staff training & $\mathrm{x} 8$ & $\begin{array}{l}\text { To what extent do companies in your country invest in training and employee } \\
\text { development? }[1 \text { = hardly at all; } 7 \text { = to a great extent] }\end{array}$ \\
\hline \multicolumn{4}{|c|}{ Second group: Labor market efficiency (Y) } \\
\hline 1 & $\begin{array}{l}\text { Cooperation in labor- } \\
\text { employer relations }\end{array}$ & Y1 & $\begin{array}{l}\text { How would you characterize labor-employer relations in your country? } \\
\text { [1=generally confrontational; } 7=\text { generally cooperative }\end{array}$ \\
\hline 2 & $\begin{array}{l}\text { Flexibility of wages } \\
\text { determination }\end{array}$ & Y2 & $\begin{array}{l}\text { How are wages generally set in your country? }[1 \text { = by a centralized bargaining } \\
\text { process; } 7=\text { up to each individual company] }\end{array}$ \\
\hline 3 & Hiring and firing practices & Y3 & $\begin{array}{l}\text { How would you characterize the hiring and firing of workers in your country? }[1= \\
\text { impeded by regulations; } 7 \text { = flexibly determined by employers] }\end{array}$ \\
\hline 4 & $\begin{array}{l}\text { Redundancy costs, weekly } \\
\text { wages }\end{array}$ & Y4 & $\begin{array}{l}\text { This variable estimates the cost of advance notice requirements, severance } \\
\text { payments, and penalties due when terminating a redundant worker, expressed } \\
\text { in weekly wages }\end{array}$ \\
\hline 5 & $\begin{array}{l}\text { Effect of taxation on work } \\
\text { incentives }\end{array}$ & Y5 & $\begin{array}{l}\text { In your country, to what extent do taxes and social contributions reduce the } \\
\text { work incentive? }[1=\text { to a great extent; } 7=\text { not at all] }\end{array}$ \\
\hline 6 & Pay and productivity & Y6 & $\begin{array}{l}\text { To what extent is pay in your country related to productivity? }[1=\text { not related to } \\
\text { worker productivity; } 7 \text { = strongly related to worker productivity] }\end{array}$ \\
\hline 7 & $\begin{array}{l}\text { Reliance on professional } \\
\text { management }\end{array}$ & Y7 & $\begin{array}{l}\text { In your country, who holds senior management positions? [ } 1 \text { = usually relatives } \\
\text { or friends without regard to merit; } 7=\text { mostly professional managers chosen for } \\
\text { merit and qualifications] }\end{array}$ \\
\hline 8 & $\begin{array}{l}\text { Country's ability to retain } \\
\text { talents }\end{array}$ & Y8 & $\begin{array}{l}\text { To what extent does your country retain talented people? }[1=\text { not at all - the } \\
\text { best and brightest leave to pursue opportunities abroad; } 7=\text { to a great extent - } \\
\text { the best and brightest stay and pursue opportunities in the country] }\end{array}$ \\
\hline 9 & $\begin{array}{l}\text { Country's ability to attract } \\
\text { talents }\end{array}$ & Y9 & $\begin{array}{l}\text { To what extent does your country attract talented people from abroad? }[1=\text { not } \\
\text { at all; } 7 \text { = to a great extent - attracts the best and brightest from around the } \\
\text { world] }\end{array}$ \\
\hline 10 & $\begin{array}{l}\text { Women in labor force, ratio } \\
\text { to men }\end{array}$ & Y10 & $\begin{array}{l}\text { Ratio of female participation in the labor force (\%) to male participation in the } \\
\text { labor force }(\%)\end{array}$ \\
\hline
\end{tabular}

Note: World Economic Forum (n.d.).

\section{DATA ANALYSIS AND THE RESULTS}

R-software packages "candisc" and "yacca" are used to perform the canonical correlation analysis. Overall model fit, standardization, loading, cross loading, redundancy, and commonality analysis are obtained using these two packages (Friendly \& Fox, 2017; Butts, 2018).

\subsection{Overall model fit}

The canonical correlation (CanR) reflects the strength of the relationship between the pairs of variates that maximize the correlation between X-indicators and Y-indicators (Dattalo, 2014, Forsyth, 2019). Table 2 gives the correlation among the eight canonical variates. The canonical correlation (CanR) between the first 
two canonical variates is 0.975 , between the second two canonical two variates - 0.778 till the last canonical correlation 0.209. Not all the eight canonical correlations are statistically significant where the usual practice is to decide functions that canonical correlation coefficient is less than $5 \%$ level of significance.

Table 2 shows Wilk's likelihood ratio test (LR test stat) and corresponding $F$-tests ( $p$-values $\operatorname{Pr}(>\mathrm{F})$ ) were used to test the null hypothesis that canonical correlations coefficients for all functions are zero. It is clear that the first six canonical correlations are significant at $5 \%$ level of significance ( $p$-values $<0.05)$.

Table 2. Results of null hypothesis testing

\begin{tabular}{c|c|c|c|c|c}
\hline CanR & LR test & Approx F & Num DF & Den DF & $\begin{array}{c}\boldsymbol{p} \text {-values } \\
\operatorname{Pr}(>\text { F) }\end{array}$ \\
\hline 0.975 & 0.004 & 12.128 & 80 & 693.55 & 0 \\
\hline 0.778 & 0.078 & 5.625 & 63 & 620 & 0 \\
\hline 0.708 & 0.198 & 4.420 & 48 & 545.31 & 0 \\
\hline 0.593 & 0.398 & 3.284 & 35 & 469.36 & 0 \\
\hline 0.437 & 0.614 & 2.446 & 24 & 391.93 & 0.001 \\
\hdashline 0.369 & 0.759 & 2.183 & 15 & 312.34 & 0.007 \\
\hdashline 0.283 & 0.879 & 1.893 & 8 & 228 & 0.062 \\
\hline 0.209 & 0.956 & 1.757 & 3 & 115 & 0.159 \\
\hline
\end{tabular}

Also, CanRSQ, given in Table 3, demonstrates the amount of variance in one canonical variate accounted for by the other variate. Table 3 shows that about $95 \%$ of variance in Xcan 1 accounted for by the Ycan1, about $61 \%$ of variance in Xcan 2 accounted for by the Ycan2, about $50 \%$ of variance in Xcan3 accounted for by the Ycan3 till the last canonical variate.

Eigenvalue represents the shared variance between the two canonical variates. Table 3 shows that the Xcan1 is sharing with Ycan1 most of the variance about 19.15 from about 22.76 (about $84.15 \%$ from total), the Xcan2 is sharing with Ycan2 about 1.533 of variance from about 22.76 (about $6.7 \%$ from total) till the last one. Moreover, the first three canonical variates are sharing about $95.3 \%$ of variance from total variance (Cum column in Table 3).
Table 3. Canonical square, eigen, percent and cumulative (Cum)

\begin{tabular}{c|c|c|c|c}
\hline CanR & CanRSQ & Eigen & Percent & Cum \\
\hline 0.975 & 0.950 & 19.156 & 84.147 & 84.15 \\
\hline 0.778 & 0.605 & 1.533 & 6.734 & 90.88 \\
\hline 0.708 & 0.501 & 1.004 & 4.413 & 95.29 \\
\hdashline 0.593 & 0.352 & 0.544 & 2.391 & 97.69 \\
\hline 0.437 & 0.191 & 0.235 & 1.035 & 98.72 \\
\hline 0.369 & 0.136 & 0.158 & 0.694 & 99.41 \\
\hline 0.283 & 0.080 & 0.087 & 0.384 & 99.80 \\
0.208 & 0.043 & 0.045 & 0.201 & 100 \\
\hline
\end{tabular}

\subsection{Standardized coefficients}

Explaining the relative contribution of an indicator by its canonical coefficient is subject to criticism unless all indicators have the same units. The standardized canonical coefficients are more reliable and give comparable results. Indicators with bigger standardized canonical coefficients give a share more to the variates. Moreover, indicators that standardized canonical coefficients have different signs show reverse relationship with each other, and indicator with standardized canonical coefficients of the same sign shows a direct relationship (Jendoubi \& Strimmer, 2019; Dattalo, 2014).

Figure 1 displays the standardized canonical coefficient and loading for the first canonical Xcan1 and Ycan1. Also, Table 4 gives the standardized canonical coefficients for the first six (significant) functions. For the higher education and training indicators $\mathrm{x} 8$ is most important, where it has the highest absolute coefficients, followed by $\mathrm{x} 6, \mathrm{x} 4, \mathrm{x} 5$, $\mathrm{x} 2, \mathrm{x} 1, \mathrm{x} 3$, and $\mathrm{x} 7$, respectively, in terms of Xcan1. For example, a one standard deviation increase in $\mathrm{x} 8$ leads to a -0.589 standard deviation increase in the score of the first canonical variate (Xcan1) when the other indicators hold constant.

Table 4. Standardized canonical coefficients for higher education and training indicators

\begin{tabular}{|c|c|c|c|c|c|c|}
\hline Indicator & Xcan1 & Xcan2 & Xcan3 & Xcan4 & Xcan5 & Xcan6 \\
\hline$x 1$ & -0.129 & -0.192 & -0.342 & 0.753 & -1.019 & 0.448 \\
\hline$x 2$ & 0.171 & 0.350 & -0.128 & -0.002 & 0.955 & 0.365 \\
\hline$\times 3$ & -0.115 & 1.470 & 2.538 & -0.432 & -1.047 & -2.120 \\
\hline$\times 4$ & -0.279 & 1.171 & -1.302 & -0.928 & -0.355 & 2.109 \\
\hline$\times 5$ & 0.265 & -1.107 & -0.960 & 2.201 & 0.853 & -1.262 \\
\hline$\times 6$ & -0.313 & -0.556 & -1.332 & -1.588 & 0.470 & -1.258 \\
\hline$\times 7$ & 0.061 & -0.744 & 0.509 & 0.369 & -0.151 & 0.733 \\
\hline$x 8$ & -0.589 & -0.010 & 0.470 & 0.195 & 0.916 & 1.594 \\
\hline
\end{tabular}




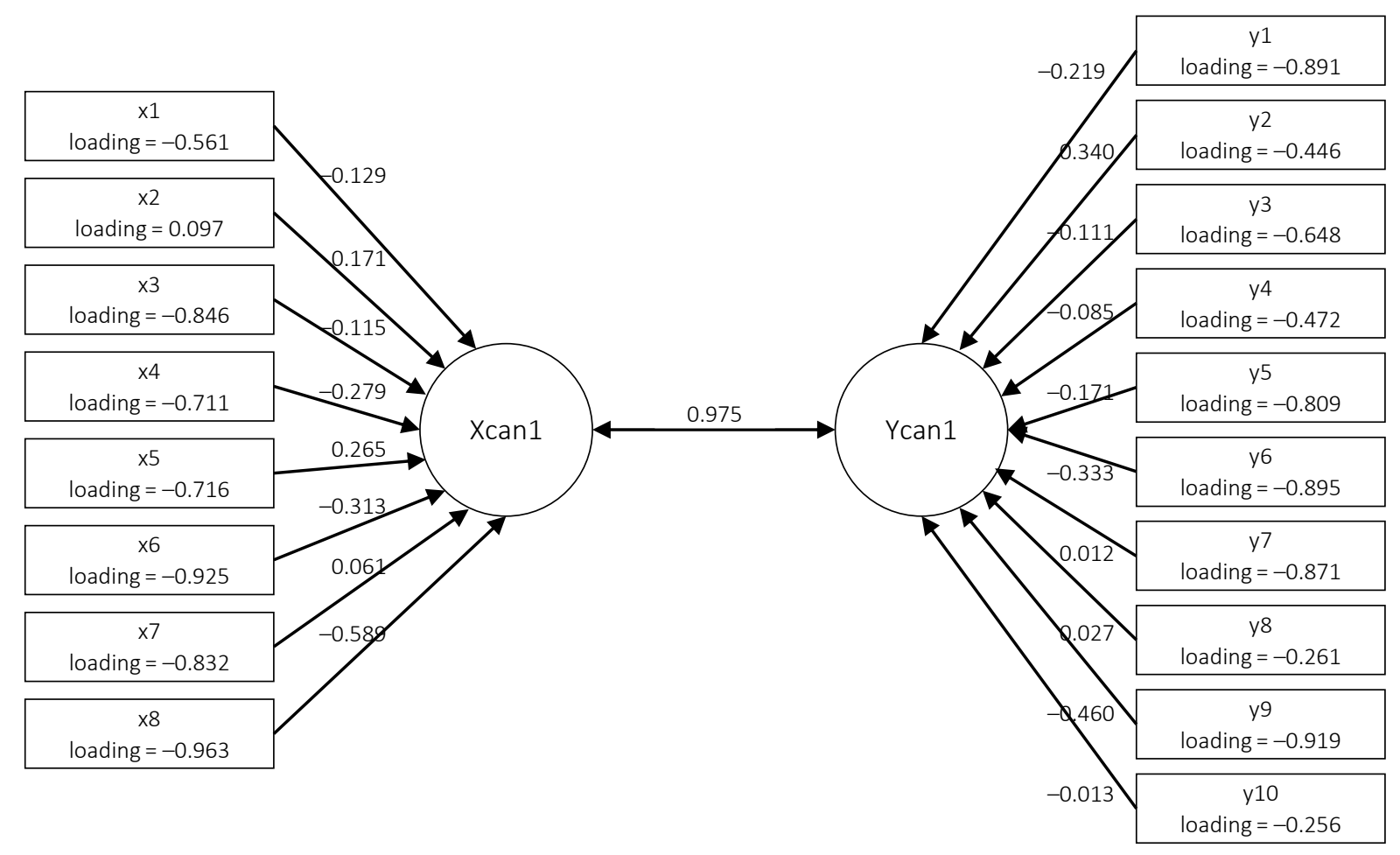

Figure 1. Canonical correlation, loading and standardized canonical coefficients for first canonical variates (Xcan1 and Ycan1)

Figure 1 displays the standardized coefficient and loading for the first canonicals Xcan1 and Ycan1. Also, Table 5 gives the standardized canonical coefficients for the first six (significant) functions. For the labour marketing efficiency indicators and regarding the sign, $\mathrm{y} 9$ is the most important indicator, followed by y2, y6, y1, y5, y3, y4, y8, y10, and y7, respectively, in terms of Ycan1. For example, a one standard deviation increase in y9 leads to a -0.460 standard deviation increase in the score of first canonical variate (Ycan1) when the other indicators hold constant.

\subsection{Structure coefficients}

The canonical structure (loading) measures the linear correlation between an observed variable in the Xcan or Ycan and that set canonical variate (Sharma, 1996; Hair et al., 1998). Figure 1 shows the standardized coefficient and loading for the first canonical Xcan1. Also, Table 6 gives the loading between higher education and training indicators and its canonical variates (Xcan). The most correlated indicator is $\mathrm{x} 8(-0.963)$ with $\mathrm{Xcan} 1$, followed by x6 (-0.925), x3 (-0.846), x7 (-0.832), x5

Table 5. Standardized canonical coefficients for labor market efficiency indicators

\begin{tabular}{|c|c|c|c|c|c|c|}
\hline Indicator & Ycan1 & Ycan2 & Ycan3 & Ycan4 & Ycan5 & Ycan6 \\
\hline y1 & -0.219 & 0.959 & 1.307 & -1.046 & -0.651 & 0.510 \\
\hline$y 2$ & 0.340 & -0.807 & 0.286 & -0.663 & 0.891 & -0.161 \\
\hline y3 & -0.111 & 0.170 & -0.399 & 0.182 & -0.284 & -0.623 \\
\hline y4 & -0.085 & 0.313 & -0.270 & -0.356 & 0.296 & 0.076 \\
\hline y5 & -0.171 & 0.118 & -0.106 & 1.089 & -0.185 & -0.211 \\
\hline y6 & -0.333 & 0.862 & 0.485 & 1.053 & 0.625 & -0.657 \\
\hline y7 & 0.012 & -0.352 & -1.249 & -0.570 & 1.086 & 0.919 \\
\hline y8 & 0.027 & 0.011 & 0.304 & -0.094 & 0.269 & 0.867 \\
\hline y9 & -0.460 & -1.288 & -0.101 & 0.128 & -1.215 & -0.249 \\
\hline y10 & -0.013 & -0.520 & -0.598 & -0.554 & -0.331 & -0.215 \\
\hline
\end{tabular}


Table 6. Loading of higher education and training indicators

\begin{tabular}{|c|c|c|c|c|c|c|}
\hline Indicator & Xcan1 & Xcan2 & Xcan3 & Xcan4 & Xcan5 & Xcan6 \\
\hline $\mathrm{x} 1$ & -0.561 & 0.073 & -0.328 & 0.090 & -0.399 & 0.159 \\
\hline$x 2$ & 0.097 & 0.517 & -0.291 & -0.003 & 0.366 & 0.179 \\
\hline$x 3$ & -0.846 & 0.400 & 0.013 & 0.206 & 0.104 & -0.182 \\
\hline$x 4$ & -0.711 & 0.495 & -0.215 & 0.259 & 0.126 & -0.057 \\
\hline$\times 5$ & -0.716 & 0.269 & -0.158 & 0.457 & 0.242 & -0.231 \\
\hline$x 6$ & -0.925 & 0.011 & -0.226 & -0.106 & 0.119 & -0.145 \\
\hline$x 7$ & -0.832 & 0.042 & 0.038 & 0.188 & 0.226 & 0.045 \\
\hline$x 8$ & -0.963 & -0.059 & 0.140 & 0.098 & 0.183 & 0.057 \\
\hline
\end{tabular}

$(-0.716), \mathrm{x} 4(-0.711), \mathrm{x} 1 \quad(-0.561)$ and $\mathrm{x} 2(0.517)$ with Xcan1, Xcan1, Xcan1, Xcan1, Xcan1, Xcan1, and $X$ can2, respectively. It can be noticed that the higher education and training indicators contribute to two dimensions Xcan1 and Xcan2.

Table 7 gives the loading between labor market efficiency indicators and its canonical variates (Ycan). The most correlated indicator is y9 $(-0.919)$ with Ycan1, followed by y6 $(-0.895)$, y1 $(-0.891)$, y7 (-0.871), y5 (-0.809), y3 (-0.648), y10 (-0.583), y8 (0.572), y4 (0.537), and y2 (-0.449) with Ycan1, Ycan1, Ycan1, Ycan1, Ycan1, Ycan4, Ycan6, Ycan2, and Ycan5, respectively. It can be noticed that the labor market efficiency indicators contribute to five dimensions Ycan1, Ycan2, Ycan4, Ycan5, and Ycan6.
Cross-loading is the linear correlation between the original variables in one variable group with the canonical variate in other variable group. Figure 2 shows the cross-loading for the first canonical variates. Table 8 shows the cross-loading between higher education and training indicators and labor market efficiency canonical variates (Ycan). The most correlated indicator is $\mathrm{x} 8(-0.939)$ with Ycan1, followed by x6 (-0.902), x3 (-0.825), x7 $(-0.811), x 5(-0.698), x 4(-0.694), x 1(-0.547)$, and x2 (0.402) with Ycan1, Ycan1, Ycan1, Ycan1, Ycan1, Ycan1, and Ycan2, respectively. In relation with Ycan, the higher education and training indicators contribute to two dimensions (Ycan1 and Ycan2).

Table 9 shows the cross-loading between labor market efficiency indicators and higher education

Table 7. Loading of labor market efficiency indicators

\begin{tabular}{|c|c|c|c|c|c|c|}
\hline Indicator & Ycan1 & Ycan2 & Ycan3 & Ycan4 & Ycan5 & Ycan6 \\
\hline y1 & -0.891 & 0.003 & 0.251 & -0.300 & 0.039 & -0.069 \\
\hline y2 & -0.447 & -0.439 & 0.414 & -0.243 & 0.449 & -0.336 \\
\hline y3 & -0.648 & -0.073 & 0.091 & -0.293 & 0.058 & -0.354 \\
\hline y4 & -0.472 & 0.537 & -0.247 & -0.254 & 0.142 & 0.074 \\
\hline y5 & -0.809 & -0.160 & 0.018 & 0.161 & 0.032 & 0.008 \\
\hline y6 & -0.895 & -0.044 & 0.100 & -0.038 & 0.311 & -0.213 \\
\hline y7 & -0.871 & -0.160 & -0.155 & -0.014 & 0.353 & 0.097 \\
\hline y8 & -0.261 & -0.212 & 0.207 & -0.161 & -0.117 & 0.572 \\
\hline y9 & -0.919 & -0.330 & 0.151 & 0.056 & 0.049 & 0.049 \\
\hline $\mathrm{y} 10$ & -0.256 & -0.124 & -0.394 & -0.583 & -0.361 & -0.204 \\
\hline
\end{tabular}

Table 8. Cross-loading of higher education and training indicators with labor market efficiency canonical variates (Ycan)

\begin{tabular}{|c|c|c|c|c|c|c|}
\hline Indicator & Ycan1 & Ycan2 & Ycan3 & Ycan4 & Ycan5 & Ycan6 \\
\hline$x 1$ & -0.547 & 0.056 & -0.233 & 0.053 & -0.174 & 0.059 \\
\hline$\times 2$ & 0.094 & 0.402 & -0.206 & -0.002 & 0.160 & 0.066 \\
\hline$\times 3$ & -0.825 & 0.311 & 0.009 & 0.122 & 0.045 & -0.067 \\
\hline$x 4$ & -0.694 & 0.385 & -0.152 & 0.154 & 0.055 & -0.021 \\
\hline$\times 5$ & -0.698 & 0.209 & -0.112 & 0.271 & 0.106 & -0.085 \\
\hline$x 6$ & -0.902 & 0.009 & -0.160 & -0.063 & 0.052 & -0.053 \\
\hline$\times 7$ & -0.811 & 0.032 & 0.027 & 0.112 & 0.099 & 0.017 \\
\hline$x 8$ & -0.939 & -0.046 & 0.099 & 0.058 & 0.080 & 0.021 \\
\hline
\end{tabular}




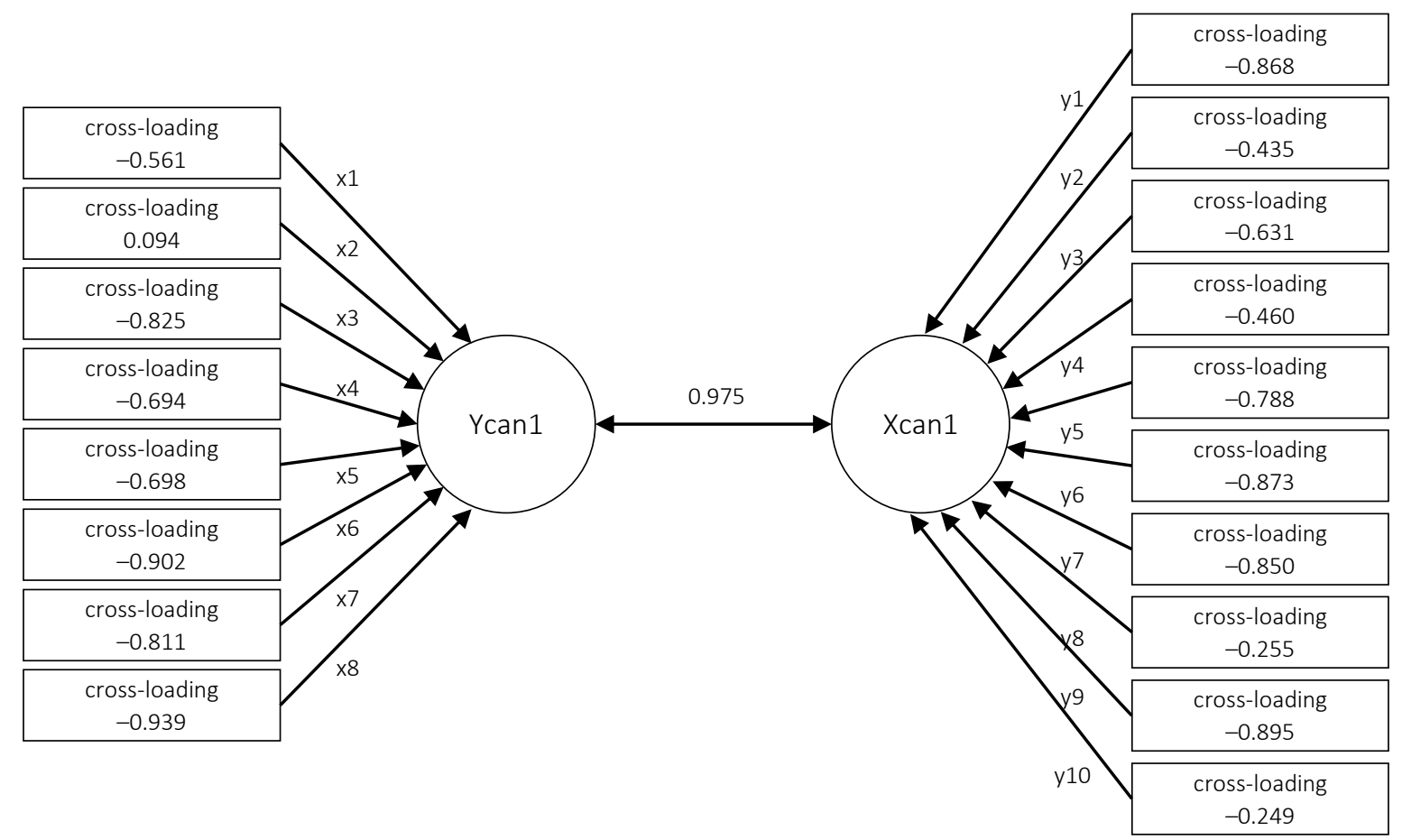

Figure 2. Canonical correlation and cross-loading for first canonical variates (Xcan1 and Ycan1)

and training canonical variates (Xcan). The most correlated indicator is y9 $(-0.895)$ with Xcan1, followed by y6 $(-0.873)$, yl $(-0.868)$, y7 $(-0.850)$, y5 (-0.788), y3 (-0.631), y4 (0.460), y2 (-0.435), y10 (-0.346), and y8(-0.255) with Xcan1, Xcan1, Xcan1, Xcan1, Xcan1, Xcan1, Xcan1, Xcan4, and Xcan1, respectively. In terms of cross-loading, the labor market efficiency indicators contribute to two dimensions only (Xcan1 and Xcan4).

\subsection{Redundancy and commonality}

Redundancy is the amount of variance in the original variables of one group of indicators that is explained by the canonical variate of the other group of indicators. High value of redundancy indicates high predictive power of the model (Dattalo, 2014; Forsyth, 2019; Nimon, Henson, \& Gates, 2010). Table 10 shows that Xcan 1 can predict about $55 \%$ of variances in the labor market indicators. About $6 \%$ of variances in labor market indicators can be explained by $\mathrm{Xcan} 2$ till the last one. In total, all X canonical variates can explain about $66 \%$ of variances in labor market indicators. Moreover, Ycan1. In other words, Ycan 1 can predict about $46 \%$ of variances in the higher education and training factor. About $4 \%$ of variances in higher education and training indicators can be explained by Ycan2 till the last one. In total, all Y canonical

Table 9. Cross-loading of labor market efficiency indicators with higher education and training canonical variates (Xcan)

\begin{tabular}{|c|c|c|c|c|c|c|}
\hline Indicator & Xcan1 & Xcan2 & Xcan3 & Xcan4 & Xcan5 & Xcan6 \\
\hline y1 & -0.868 & 0.003 & 0.177 & -0.178 & 0.017 & -0.026 \\
\hline y2 & -0.435 & -0.342 & 0.293 & -0.144 & 0.196 & -0.124 \\
\hline y3 & -0.631 & -0.057 & 0.065 & -0.174 & 0.025 & -0.131 \\
\hline y4 & -0.460 & 0.418 & -0.175 & -0.151 & 0.062 & 0.027 \\
\hline y5 & -0.788 & -0.124 & 0.013 & 0.095 & 0.014 & 0.003 \\
\hline y6 & -0.873 & -0.035 & 0.071 & -0.023 & 0.136 & -0.079 \\
\hline y7 & -0.850 & -0.124 & -0.110 & -0.008 & 0.154 & 0.036 \\
\hline y8 & -0.255 & -0.165 & 0.147 & -0.095 & -0.051 & 0.211 \\
\hline y9 & -0.895 & -0.257 & 0.107 & 0.033 & 0.021 & 0.018 \\
\hline y10 & -0.249 & -0.097 & -0.279 & -0.346 & -0.158 & -0.075 \\
\hline
\end{tabular}


variates can explain about $58 \%$ of variances in higher education and training indicators.

Table 10. Redundancy for canonical variates Xcan and Ycan

\begin{tabular}{l|c|c|c}
\hline Variate & Redundancies & Variate & Redundancies \\
\hline Xcan1 & 0.549 & Ycan1 & 0.459 \\
\hline Xcan2 & 0.057 & Ycan2 & 0.043 \\
\hdashline Xcan3 & 0.021 & Ycan3 & 0.028 \\
\hline Xcan4 & 0.017 & Ycan4 & 0.025 \\
\hdashline Xcan5 & 0.011 & Ycan5 & 0.011 \\
\hline Xcan6 & 0.003 & Ycan6 & 0.009 \\
\hline Xcan7 & 0.004 & Ycan7 & 0.004 \\
\hline Xcan8 & 0.005 & Ycan8 & 0.001 \\
\hline Total & 0.657 & Total & 0.580 \\
\hline
\end{tabular}

Commonality analysis can illustrate the canonical effects made by using the indicators in a given canonical group to partition the variance of canonical variates produced from other canonical group. These partitioning canonical variates can be divided to unique and common effects. Nimon et al. (2010) stated that a canonical commonality unique effect is computed as a squared correlation between the canonical variate for a given canon- ical set and a variable of interest in the other canonical set. A canonical commonality common effect is computed as a squared correlation between the canonical variate for a given canonical set and a set of variables of interest from the other canonical set after subtracting all unique effects and the variance explained by any other sets of variables.

Table 11 shows the partitioning of higher education and training canonical first variate by the variables in the labor market efficiency and the partition of labor market efficiency canonical first variate by the variables in the higher education and training indicators. The values indicate how much variance was explained uniquely and in common by the indicators and the \% total indicates the percentage of variance explained out of the observed canonical effect. Table 11 reveals that the higher education and training variate was explained by variance common to y1, y2, y3, y5, y6, y7 (15.28\%) of canonical effect, followed by yl, y5, $y 6, y 7, y 9$ (13.02\%), while the unique contribution of these indicators is very low. Also, Table 11 indicates that the labor market efficiency variate was explained by variance common to $\mathrm{x} 3, \mathrm{x} 4, \mathrm{x} 5, \mathrm{x} 6$, x7, x8 (30.46\%) of canonical effect, followed by x1, $\mathrm{x} 3, \mathrm{x} 5, \mathrm{x} 6, \mathrm{x} 7, \mathrm{x} 8(20.43 \%)$, while the unique contribution of these indicators is very low.

Table 11. Partitioning of the variances of canonical variates to unique and common effects based on commonality analysis

\begin{tabular}{|c|c|c|c|c|c|}
\hline \multicolumn{4}{|c|}{ Partitioning of function $X$ canonical variate } & \multicolumn{2}{|c|}{$\begin{array}{l}\text { Partitioning of function } \\
\text { Y canonical variate }\end{array}$} \\
\hline Indicator & Unique & $\%$ total & Indicator & Unique & $\%$ total \\
\hline y1 & 0.0080 & 0.84 & $x 1$ & 0.0070 & 0.74 \\
\hline y2 & 0.0464 & 4.88 & $x 2$ & 0.0174 & 1.83 \\
\hline y3 & 0.0034 & 0.36 & x3 & 0.0010 & 0.11 \\
\hline y4 & 0.0046 & 0.49 & $x 4$ & 0.0063 & 0.67 \\
\hline y5 & 0.0084 & 0.88 & $x 5$ & 0.0071 & 0.74 \\
\hline y6 & 0.0118 & 1.24 & $x 6$ & 0.0131 & 1.38 \\
\hline y7 & 0 & 0 & $x 7$ & 0.0006 & 0.06 \\
\hline y8 & 0.0004 & 0.04 & $x 8$ & 0.0465 & 4.89 \\
\hline y9 & 0.0275 & 2.89 & & & \\
\hline y10 & 0.0031 & 0.46 & & & \\
\hline \multicolumn{4}{|c|}{ Highest three commons } & \multicolumn{2}{|c|}{ Highest three commons } \\
\hline y1, y4, y5, y6, y7, y9 & 0.0794 & 8.36 & $x 3, x 6, x 7, x 8$ & 0.0494 & 5.20 \\
\hline y1, y5, y6, y7, y9 & 0.1237 & 13.02 & $x 1, x 3, x 5, x 6, x 7, x 8$ & 0.1941 & 20.43 \\
\hline$y 1, y 2, y 3, y 5, y 6, y 7$ & 0.1452 & 15.28 & $x 3, x 4, x 5, x 6, x 7, x 8$ & 0.2895 & 30.46 \\
\hline
\end{tabular}




\section{CONCLUSION}

The canonical correlation analysis is used as a bidirectional technique to explore the determinant factors and analyze the relationship between higher education and training and labor market efficiency in MENA countries using data from reports published from 2012 till 2018 by World Economic Forum (WEF). The results from loading and cross loading coefficients have suggested that the most relative important indicators in education are the extent of staff training, internet access, quality of education, quality of management schools and local availability of specialized training services, quality of math and science education, secondary education and tertiary education enrolment, while the most important indicators in labor market efficiency are the capacity to attract talent, pay and productivity, cooperation in labor employer relations, reliance on professional management, effect of taxation on incentives to work, hiring and firing practices, women in labor, country's ability to retain talent, redundancy cost, and flexibility of wage determination.

The commonality analysis gives more interesting results and suggests that a unique indicator has very low percentage of explained variance, while the large percentage of explained variance back to common indicators. The commonality analysis has indicated that the labor market efficiency factor was explained mostly by quality of education system, quality of math and science education, quality of management school, internet access, local availability of specialized training system, extent of staff training. The higher education and training factors were explained mostly by cooperation in labor employer relations, flexibility of wage determination, hiring and firing practices, effect of taxation on incentives to work, pay and productivity, reliance on professional management. Therefore, the decision-makers in MENA countries could benefit from this study by considering the most important indicators in each group to quickly improve the higher education and training and the labor market efficiency factors and, consequently, boost economic growth.

\section{AUTHOR CONTRIBUTIONS}

Data curation: Elsayed A. H. Elamir.

Formal analysis: Elsayed A. H. Elamir.

Methodology: Elsayed A. H. Elamir.

Software: Elsayed A. H. Elamir.

Writing - original draft: Elsayed A. H. Elamir.

Writing - review \& editing: Elsayed A. H. Elamir.

\section{REFERENCES}

1. Allen, J., \& Velden, V. R. (2007). The flexible professional in the knowledge society: General rules of the REFLEX project. Maastricht, The Netherlands: Research Centre for Education and the Labour Market, Maastricht University. Retrieved from https://www.springer.com/gp/ book/9789400713529

2. Arthur, L. (2006). Higher education and the area of work: Issues, challenges and responses in Norway and Germany. Research in Comparative and International Education, 3(1), 241-252.
https://doi.org/10.2304\%2Frc ie.2006.1.3.241

3. Assaad, R., \& Krafft, C. (2016). Labour market dynamics and youth unemployment in the Middle East and North Africa: Evidence from Egypt, Jordan and Tunisia. Economic Research Forum Working Paper Series No. 993. Cairo, Egypt. Retrieved from https://erf.org.eg/wp-content/uploads/2016/04/993.pdf

4. Assaad, R., Krafft, C., \& SalehiIsfahani, D. (2018). Does the type of higher education affect labour market outcomes? evidence from Egypt and Jordan. High Educ (Dordr), 75(6), 945-995. Retrieved from https://www.ncbi.nlm.nih. gov/pubmed/29937553

5. Becker, G. S. (1962). Investment in human capital: A theoretical analysis. Journal of Political Economy, 70(5), 9-49. Retrieved from https://www.nber.org/chapters/c13571

6. Becker, G. S. (1993). The economic way of looking at behavior. Journal of Political Economy, 101(5), 385-409. 
Retrieved from https://www.jstor. org/stable $/ 2138769$ ? seq $=1$

7. Boccanfuso, D., Larouche, A., \& Trandafir, M. (2015). Quality of Higher Education and the labour market in developing countries: Evidence from an education reform in Senegal (IZA Discussion Paper No. 9099). https://doi.org/10.1016/j.worlddev.2015.05.007

8. Boeri, T., \& Garibaldi, P. (2007). Two Tier reforms of employment protection: A Honeymoon effect? Economic Journal, 117(521), 357-385. https://doi.org/10.1111/ j.1468-0297.2007.02060.x

9. Butts, C. (2018). Yacca: yet another canonical correlation analysis. Retrieved from https://cran.rproject.org/web/packages/yacca/ index.html

10. Dattalo, P. (2014). A demonstration of canonical correlation analysis with orthogonal rotation to facilitate interpretation. Unpublished manuscript, School of Social Work, Virginia Commonwealth University, Richmond, Virginia. Retrieved from https://scholarscompass.vcu.edu/cgi/viewcontent .cgi? article $=1001 \&$ context $=$ soc ialwork_pubs

11. Dalton, J., \& Smith, P (2004). Vocational education and training in secondary schools: Challenging teachers' work and identity. Journal of Vocational Education and Training, 56(4), 507-521. https://doi. org/10.1080/13636820400200267

12. Dolado, J. J., Ortigueria, S., \& Stucchi, R. (2012). Does dual employment protection affect TFP? Evidence from Spanish manufacturing firms (CEPR Discussion Paper No. DP8763). Retrieved from https://link. springer.com/article/10.1007/ s13209-016-0150-9

13. Fofack, H. (2009). Determinants of Globalization and Growth Prospects for Sub-Saharan African Countries. Retrieved from http:// documents.worldbank.org/curated/en/259011468191940648/pdf/ WPS5019.pdf
14. Forsyth, D. (2019) Canonical correlation analysis. Applied Machine Learning, Springer, Cham.

15. Friendly, M., \& Fox, J. (2017). Candisc: visualizing generalized canonical discriminant and canonical correlation analysis. Retrieved from https://cran.rproject.org/web/packages/candisc/ index.html

16. Garcia, M., \& Fares, J. (2008). Youth in Africa's Labour Market. Washington: The International Bank for Reconstruction and Development, The World Bank.

17. World Economic Forum (n.d.). Global Competitiveness Report (from 2011-2012 to 2017-2018). Retrieved from https://www. weforum.org/reports/theglobalcompetitiveness-report (accessed different dates in March 2019).

18. Hair, J. F.., Anderson, R. E., Tatham, R. L., \& Black, W. C. (1998). Multivariate data analysis. New York: Prentice Hall.

19. Hanushek, E. A. (2013). Economic growth in developing countries: The role of human capital. Economics of Education Review, 37, 204-212. https://doi.org/10.1016/j. econedurev.2013.04.005

20. Jendoubi, T., \& Strimmer, K. (2019). A whitening approach to probabilistic canonical correlation analysis for omics data integration. BMC Bioinformatic, 20(15), 72-79. Retrieved from https://arxiv.org/ ct?url=https\%3A\%2F\%2Fdx.doi. org\%2F10.1186\%2Fs12859-0182572-9\&v=9474bfee

21. Kaarsen, N. (2014). Cross-country differences in the quality of schooling. Journal of Development Economics, 107, 215-224. https://doi.org/10.1016/j.jdeveco.2013.11.005

22. Kehm, B. (1997). Relationship between higher education and the labour market and the European mobility programmes. Summer course in Higher Education Policy and Institutional Decision Making. Budapest, Central European University.

23. Knapp, T. R. (1978). Canonical correlation analysis: A general parametric significance testing system. Psychological Bulletin, 85(2), 410-416. Retrieved from https://psycnet.apa.org/record/1979-00149-001

24. Kuczera, M., \& Field, S. (2010). Learning for jobs: OECD reviews of vocational education and training: Options for China. OECD, Paris. Retrieved from www.oecd.org/ dataoecd/36/36/45486493.pdf

25. Little, B. (2007, March 22). Labour market issues and international employability, Employability seminar, Sheffield Hallam University.

26. Manuelli, R. E., \& Seshadri, A. (2014). Human capital and the wealth of nations. American Economic Review, 104(9), 27362762. Retrieved from https://www. aeaweb.org/articles?id=10.1257/ aer.104.9.2736

27. Mincer, J., \& Polachek, S. (1974). Family investment in human capital: Earning of women. Journal of Political Economy, 82(2), 576587. Retrieved from https://www. jstor.org $/$ stable $/ 1829993$ ? seq=1

28. Mousa, G. A., \& Elamir, A. H. E. (2019). The association between technological readiness and higher education: The case of Middle East countries (3ICT Conference). University of Bahrain, Zain eLearning center.

29. Nicolescu, L., \& Paun, C. (2009). Relating Higher Education with the Labour Market: Graduates expectations and employers' requirements. Tertiary Education and Management, 15(1), 17-33. https://doi. org/10.1080/13583880802700024

30. Nimon, K., Henson, R. K., \& Gates, M. S. (2010). Revisiting interpretation of canonical correlation analysis: A Tutorial and demonstration of canonical commonality analysis. Multivariate Behavioral Research, 45(4), 702-724. Retrieved from https://www.researchgate.net/ publication/247503568_Revisiting_Interpretation_of_Canonical_ Correlation_Analysis_A_Tutorial_ and_Demonstration_of_Canonical_Commonality_Analysis 
31. Pages, C., \& Stampini, M. (2009). No education, No good jobs? Evidence on the relationship between Education and Labour market segmentation. Journal of Comparative Economics, 37(3), 387-401. https://doi.org/10.1016/j. jce.2009.05.002

32. Porter, M. E., \& Schwab, K. (2008). The Global Competitiveness Report 2008-2009. Geneva: World Economic Forum.

33. Rosen, S. (1983). Specialization and human capital. Journal of Labour Economics, 1(1), 43-49. Retrieved from https://www.jstor. org/stable/2534930

34. Saunders, M., \& Machell, J. (2000). Understanding emerging trends in higher education curricula and work connections. Higher Education Policy, 13(3), 287-302. https://doi.org/10.1016/S09528733(00)00013-1

35. Schoellman, T. (2012). Education quality and development accounting. Review of Economic Studies, 79(1), 388-417. https://doi. org/10.1093/restud/rdr025
36. Sharma S. (1996). Applied multivariate techniques. John Wiley \& Sons.

37. Stevens, J. (1996). Applied multivariate statistics for the social sciences. Hillsdale, NJ: Erlbaum.

38. Teichler, U. (1999). Research on the relationship between higher education and the world of work: Past achievements, problems and new challenges. Higher Education, 38, 169-190. Retrieved from https://link.springer.com/ article/10.1023/A:1003761214250

39. Teichler, U., \& Schomburg, H. (2006). Higher education and graduate employment in Europe: Results from graduate surveys from 12 countries. Higher Education Dynamics, 15(Series). Dordrecht: Springer.

40. Tellegen, B. G. (2013). The relationship between education and the labour market in the current context of Sub-Saharan Africa (Master Thesis). Utrecht University.
41. Thisse, J. F., \& Zenou, Y. (2007). Skills mismatch and unemployment. Economics Letters, 69(3), 415-420. https:// doi.org/10.1016/S01651765(00)00334-7

42. Warner, R. M. (2008). Applied statistics: From bivariate through multivariate techniques. Los Angeles, CA: Sage Publications.

43. World Regional Report (2010). Higher Education, productivity, and labour market insertion: are MENA countries getting results? Retrieved from http:// siteresources.worldbank.org/ MENAEXT/Resources/Financing_Higher_Education_Middle_ East_Chapter1_English.pdf

44. World Regional Report (2011). MENA facing challenges and opportunities. Retrieved from http://siteresources.worldbank. org/INTMENA/Resources/ MENAFacingChallengestextjuly13.pdf 